\title{
Pengaruh Penggunaan Pupuk Cair Organik (POC) Bonggol Pisang Terhadap Produksi Tanaman Caisim (Brassica juncea L.) Sistem Wick
}

\author{
Zul Fahmi, Suryani, dan Siti M. Sholihah \\ Program Studi Agroteknologi Fakultas Pertanian Universitas Respati Indonesia \\ Email : zulfahmioisca@gmail.com
}

\begin{abstract}
Abstrak
Caisim (Brassica juncea L.) merupakan salah satu jenis sayuran yang mudah tumbuh di Indonesia dan biasa dimanfaatkan sebagai bahan makanan pokok masyarakat. Pengembangan budidaya caisim mempunyai prospek baik untuk mendukung upaya peningkatan pendapatan petani dan peningkatan gizi masyarakat. Pemanfaatan bonggol pisang dan limbah air beras sebagai pupuk organik cair merupakan alternatif yang dapat dilakukan sebagai pemanfaatan dan pengolahan limbah pertanian agar dapat menciptakan pertanian berkelanjutan. Penelitian ini bertujuan untuk mengetahui respon pertumbuhan dan perkembangan tanaman Caisim pada berbagai konsentrasi nutrisi ABmix dan Pupuk Organik Cair (POC) Bonggol Pisang dengan sistem wick. Penelitian ini dilaksanakan di kebun percobaan kampus B Fakultas Pertanian Universitas Respati Indonesia pada Juli sampai dengan Agustus 2020. Penelitian menggunakan Rancangan Acak Kelompok (RAK) non faktorial dengan 4 taraf konsentrasi paket nutrisi $A B m i x$ dan Pupuk Organik Cair (POC) Bonggol Pisang yaitu: $\mathrm{P} 1=\mathrm{ABmix} 4,5 \mathrm{ml} / \mathrm{L}$ air $+\mathrm{POC} 100 \mathrm{ml} / \mathrm{L}$ air, $\mathrm{P} 2=A B \operatorname{mix}$ $6,5 \mathrm{ml} / \mathrm{L}$ air + POC $70 \mathrm{ml} / \mathrm{L}$ air, $\mathrm{P} 3=A B \operatorname{mix} 8,5 \mathrm{ml} / \mathrm{L}$ air $+P O C 40 \mathrm{ml} / \mathrm{L}$ air dan $\mathrm{P} 4=$ $A B \operatorname{mix} 10,5 \mathrm{ml} / \mathrm{L}$ air. Parameter yang diamati yaitu tinggi tanaman, jumlah daun, luas daun dan bobot segar tanaman. Hasil penelitian ini menunjukkan bahwa terdapat pengaruh berbeda antara perlakuan berbagai konsentrasi nutrisi ABmix dan POC Bonggol Pisang dengan perlakuan yang lainnya terhadap pertumbuhan tanaman Caisim (Brassica juncea L.) dengan sistem wick. Penggunaan konsentrasi nutrisi ABmix dan POC Bonggol Pisang yang paling baik pada umur 35 HST adalah dosis $A B \operatorname{mix} 8,5 \mathrm{ml} / \mathrm{L}$ air $+P O C 40 \mathrm{ml} / \mathrm{L}$ air dengan hasil tinggi tanaman $(21,3 \mathrm{~cm})$, jumlah daun (9 helai), luas daun $\left(3,14 \mathrm{~cm}^{2}\right)$, bobot segar tanaman $(22,14 \mathrm{gr})$.
\end{abstract}

Kata kunci: Hidroponik, Sistem Wick, POC Bonggol Pisang, ABmix, Caisim

\section{Abstract \\ Caisim (Brassica juncea L.) is a type of vegetable that is easy to grow in Indonesia and} is commonly used as a staple food for the community. Caisim cultivation development has good prospects to support efforts to increase farmers' income and improve community nutrition. Utilization of banana weevil and rice water waste as liquid organic fertilizer is an alternative that can be used as utilization and processing of agricultural waste in order to create sustainable agriculture. This study aims to determine the response to growth and development of Caisim plants at various nutrient concentrations of ABmix and Banana Weevil Liquid Organic Fertilizer (POC) with the wick system. This research was conducted in the experimental garden of campus B, Faculty of Agriculture, Respati Indonesia University from July to August 2020. The research used a non-factorial randomized block design (RAK) with 4 levels of concentration of the ABmix nutrient package and Banana Weevil Liquid Organic

\section{http://ejournal.urindo.ac.id/index.php/pertanian}


Fertilizer (POC), namely: $\mathrm{P} 1=\mathrm{ABmix} 4.5 \mathrm{ml} / \mathrm{L}$ water $+\mathrm{POC} 100 \mathrm{ml} / \mathrm{L}$ water, $\mathrm{P} 2=\mathrm{ABmix} 6.5 \mathrm{ml}$ / L water + POC $70 \mathrm{ml} / \mathrm{L}$ water, P3 = ABmix $8.5 \mathrm{ml} / \mathrm{L}$ water $+\mathrm{POC} 40 \mathrm{ml} / \mathrm{L}$ water and P4 = $A B m i x 10.5 \mathrm{ml} / \mathrm{L}$ water. The parameters observed were plant height, number of leaves, leaf area and plant fresh weight. The results of this study indicated that there was a different effect between the treatment of various nutrient concentrations of ABmix and Banana Weevil POC and other treatments on the growth of Caisim (Brassica juncea L.) plants with the wick system. The best use of $A B$ mix and banana weevil nutrient concentrations at the age of 35 DAS is a dose of $A B$ mix $8.5 \mathrm{ml} / \mathrm{L}$ water + POC $40 \mathrm{ml} / \mathrm{L}$ water with plant height $(21.3 \mathrm{~cm})$, number of leaves (9 pieces), leaf area (3.14 cm2), plant fresh weight $(22.14 \mathrm{~g})$.

Keywords: Hydroponics, Wick System, Banana Weevil POC, ABmix, Caisim

\section{PENDAHULUAN}

Sayuran merupakan komoditi yang mempunyai prospek besar karena dibutuhkan oleh masyarakat, selain itu sayuran juga memiliki kandungan gizi yang baik untuk kesehatan, di antaranya protein, lemak, karbohidrat, $\mathrm{Ca}, \mathrm{P}, \mathrm{Fe}$, Vitamin $\mathrm{A}$, Vitamin B, Vitamin C, dan serat [1]. Banyak masyarakat menyukai sayuran ini karena caisim memiliki rasa yang lezat serta mengandung vitamin dan mineral yang baik untuk Kesehatan [2]. Caisim (Brassica juncea L.) merupakan salah satu jenis sayuran yang mudah tumbuh di Indonesia dan biasa dimanfaatkan sebagai bahan makanan pokok masyarakat. Caisim merupakan tanaman yang dapat tumbuh dengan iklim sub-tropis, pada umumnya banyak dibudidayakan pada dataran rendah, namun dapat juga didataran tinggi [1]. Pengembangan budidaya caisim mempunyai prospek baik untuk mendukung upaya peningkatan pendapatan petani dan peningkatan gizi masyarakat. Beberapa manfaat caisim untuk kesehatan tubuh adalah menyehatkan tulang, mencegah kangker, baik untuk diabetes, menyehatkan kulit dan rambut, membantu tidur dan suasana hati [3].

Produksi sayuran caisim di Indonesia dari tahun 2014 sampai 2018 mengalami kenaikan dari $602.468 \mathrm{~kg}$, menjadi $635.988 \mathrm{~kg}$, namun mulai tahun 2014 sampai 2015 telah mengalami mengalami penurunan dari $602.468 \mathrm{~kg}$ lalu menjadi $600.200 \mathrm{~kg}$ [4]. Data tersebut menunjukan bahwa terjadi fluktuasi produksi tanaman caisim, dalam 3 tahun terakhir produksi caisim telah mengalami penurunan. Budidaya caisim masih ditemukan kendala yang menyebabkan terjadinya penurunan produksi, perlu adanya peningkatan produksi dengan perbaikan teknologi dalam budidaya tanaman caisim.

Budidaya caisim pada umumnya hanya dilakukan dengan cara konvensional 
tetapi seiring dengan perkembangan zaman dapat juga dilakukan dengan teknik hidroponik. Salah satu sistem hidroponik sederhana ialah sistem wick. Dalam sistem hidroponik ini, wick untuk alat penyaluran nutrisi bagi tanaman pada media tanam. Larutan nutrisi diserap ke media tanam dari bak penampungan melalui kain panel. Air dan nutrisi akan dapat mencapai akar tanaman dengan memanfaatkan daya kapilaritas pada kain panel. Sistem bersifat pasif, dikarenakan tidak adanya bagian yang bergerak pada media ini [5].

Faktor keberhasilan budidaya sayuran secara hidroponik adalah nutrisi yang digunakan, nutrisi sangat penting untuk keberhasilan dalam menanam secara hidroponik, karena tanpa nutrisi pertumbuhan tanaman akan terhambat serta tidak dapat memberikan hasil dan produksi sayuran yang maksimal. Nutrisi merupakan hara makro dan mikro yang harus ada untuk pertumbuhan tanaman [5].

Budidaya sayuran secara hidroponik, selain menggunakan ABmix, dapat menggunakan POC untuk menekan penggunaan pupuk anorganik. Sayuran yang sehat ditentukan oleh kualitas pupuk yang digunakan salah satu jenis pupuk organik cair yaitu pupuk oranik cair bonggol pisang [6]. Pupuk organik cair dengan bahan dasar limbah organik dari bonggol pisang kapok dan limbah air beras yang di buat melalui proses fermentasi. Di dalam bonggol pisang kepok terdapat 7 Jenis mikrobia yang sangat berguna bagi tanaman antara lain Azospirillium, Azotobacter, Bacillus sp., Aeromonas sp, Aspergillus nigger, mikroba pelarut phospat dan mikroba selulotik. Mikrobia inilah yang biasa mendekomposisi bahan organik. Berdasarkan hal tersebut maka penggunaan MOL bonggol pisang sebagai decomposer [7].

\section{METODE}

Penelitian ini dilaksanakan di kebun percobaan kampus B Fakultas Pertanian Universitas Respati Indonesia, mulai bulan Juli sampai dengan bulan Agustus 2020. Alat yang digunakan dalam penelitian ini adalah instalasi sistem wick, EC meter/TDS meter, $\mathrm{pH}$ meter, dan kontainer 60 liter. Bahan yang digunakan dalam penelitian ini adalah benih caisim varietas tosakan, rockwool, nutrisi $A B m i x$, dan bonggol pisang.

Penelitian ini menggunakan Rancangan Acak Kelompok (RAK) non faktorial yang terdiri dari 4 perlakuan dan 5 ulangan, sehingga diperoleh 20 satuan percobaan. Konsentrasi nutrisi ABmix dan POC (P) yang terdiri atas 4 taraf yaitu: P1 (ABmix 4,5 ml/L air + POC $100 \mathrm{ml} / \mathrm{L}$ air), P2 (ABmix 6,5 ml/L air + POC $70 \mathrm{ml} / \mathrm{L}$ 
air), P3 (ABmix 8,5 ml/L air + POC $40 \mathrm{ml} / \mathrm{L}$ air), dan P4 (ABmix 10,5 ml/L air).

Parameter penelitian meliputi tinggi tanaman $(\mathrm{cm})$, jumlah daun (helai), luas daun $\left(\mathrm{cm}^{2}\right)$, dan bobot segar tanaman (g). Data yang diperoleh dianalisa menggunakan Analisis Ragam (ANOVA), pada tingkat signifikan 5\%. Apabila terdapat perbedaan di antara perlakuan dilanjutkan dengan uji Beda Nyata Terkecil (BNT).

\section{HASIL DAN PEMBAHASAN}

\section{Tinggi Tanaman}

Berdasarkan Analisa sidik ragam, menunjukkan bahwa perlakuan konsentrasi $\mathrm{ABmix}$ dan POC Bonggol Pisang berbeda sangat nyata terhadap tinggi tanaman Caisim. Hasil rata-rata tinggi tanaman sebagaimana tertera pada Tabel 1. Pada umur 21 HST, 28 HST, 35 HST mulai terlihat perbedaan yang signifikan terhadap pertumbuhan tinggi tanaman pada setiap perlakuan konsentrasi larutan POC Bonggol Pisang dan ABmix. Pada perlakuan dengan konsentrasi ABmix 10,5 $\mathrm{ml} / \mathrm{L}$ air menghasilkan tinggi tanaman yang terbesar, walupun tidak berbeda dengan konsentrasi ABmix 8,5 ml/L air + POC 40 $\mathrm{ml} / \mathrm{L}$ air $\left(21,3 \mathrm{~cm}^{2}\right)$.

Hal ini disebabkan karena perkembangan tinggi tanaman dipengaruhi oleh kandungan nutrisi dari bonggol pisang dan limbah cucian beras yang terdekomposisi oleh mikrobia Bacillus sp., Aeromonas sp., dan Aspergillus nigger yang terkandung didalam bonggol pisang. Bonggol Pisang mengandung 3087 ppm NO3, 1120 ppm NH4, 439 ppm P2O5 dan 574 ppm K2O [8]. Limbah air beras mengandung nutrisi terlarut diantaranya $80 \%$ vitamin B1, $70 \%$ vitamin B3, $90 \%$ vitamin $\mathrm{B} 6$, $50 \%$ mangan, $50 \%$ fosfor, $60 \%$ zat besi [9].

Tabel 1. Rekapitulasi Hasil Uji BNT 5\% Pengaruh Penggunaan POC Bonggol Pisang terhadap Tinggi Tanaman Caisim

\begin{tabular}{lrccc}
\hline \multirow{2}{*}{ Perlakuan } & \multicolumn{4}{c}{ Rata-rata Tinggi Tanaman (cm) } \\
\cline { 2 - 5 } & $14 \mathrm{HST}$ & $21 \mathrm{HST}$ & $28 \mathrm{HST}$ & $35 \mathrm{HST}$ \\
\hline $\mathrm{P} 1: \mathrm{ABmix} 4,5 \mathrm{ml} / \mathrm{L}$ air + POC 100 & $4,26 \mathrm{a}$ & $10,58 \mathrm{ab}$ & $11,75 \mathrm{a}$ & $15,75 \mathrm{a}$ \\
$\mathrm{ml} / \mathrm{L}$ air & & & & \\
P2: ABmix 6,5 ml/L air + POC 70 & $4,50 \mathrm{a}$ & $7,30 \mathrm{a}$ & $9,70 \mathrm{a}$ & $13,00 \mathrm{a}$ \\
$\mathrm{ml} / \mathrm{L}$ air & & & & \\
P3: ABmix 8,5 ml/L air + POC 40 & $5,30 \mathrm{~b}$ & $10,60 \mathrm{ab}$ & $14,60 \mathrm{~b}$ & $21,30 \mathrm{~b}$ \\
$\mathrm{ml} / \mathrm{L}$ air & & & & \\
P4: ABmix 10,5 ml/L air & $5,30 \mathrm{~b}$ & $22,00 \mathrm{~b}$ & $31,00 \mathrm{~b}$ & $35,00 \mathrm{~b}$ \\
\hline
\end{tabular}

Keterangan: Angka yang didampingi huruf yang sama pada kolom yang sama, berarti tidak berbeda nyata menurut uji BNT 5\%

\section{Jumlah Daun}


Berdasarkan analisa sidik ragam menunjukkan bahwa perlakuan konsentrasi $\mathrm{ABmix}$ dan $\mathrm{POC}$ Bonggol Pisang berbeda sangat nyata terhadap jumlah daun tanaman Caisim. Hasil rata-rata jumlah daun sebagaimana tertera pada Tabel 2. Pada perlakuan dengan dosisi ABmix 10,5 $\mathrm{ml} / \mathrm{L}$ air menunjukkan menghasilakn jumlah daun terbesar $(12,2$ helai), walaupun tidak berbeda dengan konsentrasi $A B m i x$ 8,5 ml/L air + $P O C$ Bonggol Pisang $40 \mathrm{ml} / \mathrm{L}$ air (9 helai). Konsentrasi ABmix 4,5 ml/l aor + POC 100 $\mathrm{ml} / \mathrm{l}$ air, menghasilan jumlah daun terendah.

Tabel 2. Rekapitulasi Hasil Uji BNT 5\% Pengaruh Penggunaan POC Bonggol Pisang terhadap Jumlah Daun Tanaman Caisim

\begin{tabular}{|c|c|c|c|c|}
\hline \multirow{2}{*}{ Perlakuan } & \multicolumn{4}{|c|}{ Rata-rata Jumlah Daun (helai) } \\
\hline & $14 \mathrm{HST}$ & $21 \mathrm{HST}$ & 28 HST & 35 HST \\
\hline $\begin{array}{c}\mathrm{P} 1: \mathrm{ABmix} 4,5 \mathrm{ml} / \mathrm{L} \text { air }+\mathrm{POC} \\
100 \mathrm{ml} / \mathrm{L} \text { air }\end{array}$ & $5,00 \mathrm{a}$ & $6,20 \mathrm{a}$ & $7,20 \mathrm{a}$ & $8,20 \mathrm{a}$ \\
\hline $\begin{array}{c}\mathrm{P} 2: \mathrm{ABmix} 6,5 \mathrm{ml} / \mathrm{L} \text { air }+\mathrm{POC} \\
70 \mathrm{ml} / \mathrm{L} \text { air }\end{array}$ & $4,20 \mathrm{a}$ & $5,00 \mathrm{a}$ & $6,00 \mathrm{a}$ & $6,60 a$ \\
\hline $\begin{array}{c}\text { P3 : ABmix 8,5 ml/L air + POC } \\
40 \mathrm{ml} / \mathrm{L} \text { air }\end{array}$ & $5,40 \mathrm{~b}$ & $6,40 \mathrm{~b}$ & $8,40 \mathrm{~b}$ & $9,00 \mathrm{~b}$ \\
\hline P4 : ABmix 10,5 ml/L air & $5,60 \mathrm{~b}$ & $9,20 \mathrm{~b}$ & $10,60 \mathrm{~b}$ & $12,20 \mathrm{~b}$ \\
\hline
\end{tabular}

Keterangan: Angka yang didampingi huruf yang sama pada kolom yang sama, berarti tidak berbeda nyata menurut uji BNT 5\%

Jumlah daun disebabkan oleh unsur hara nitrogen yang terkandung di dalam nutrisi ABmix lebih lengkap dibandingkan dengan POC Bonggol Pisang. Hal ini berpengaruh terhadap kandungan klorofil dalam daun sehingga terjadi peningkatan jumlah daun, dimana klorofil di dalam daun berperan sebagai alat penyerapan cahaya sehingga terjadi proses fotosintesis. Apabila kandungan klorofil dalam daun cukup tersedia maka proses fotosintesis yang dihasilkan juga akan meningkat [10].

Bonggol Pisang mengandung 3087 ppm NO3, 1120 ppm NH4, 439 ppm P2O5 dan 574 ppm K2O [8]. Limbah air beras memiliki kandungan unsur hara nitogen, fosfor, magnesium dan sulfur yang tinggi diantaranya adalah N 0,015\%, P 16,306\%, K 0,02\%, Ca 2,944\%, Mg 14,252\%, S 0,027\%, Fe 0,0427\% dan B1 0,043\%. Limbah air beras mengandung zat pengatur tumbuh. ZPT pada tanaman yang berperan merangsang pembentukan akar dan batang serta pembentukan cabang akar dan batang dengan menghambat dominasi apical dan pembentukan daun muda [9].

\section{Luas Daun}

Berdasarkan analisis sidik ragam menunjukkan bahwa perlakuan 
konsentrasi $\mathrm{ABmix}$ dan POC Bonggol Pisang

berbeda sangat nyata terhadap luas daun tanaman Caisim. Hasil rata-rata luas daun sebagaimana tertera pada Tabel 3. Hasil pengamatan menunjukkan bahwa konsentrasi ABmix 10,5 $\mathrm{ml} / \mathrm{l}$ air menghasilkan luas daun terbesar $(7,46$ $\mathrm{cm}^{2}$ ), walaupun tidak berbeda dengan konsentrasi $A B \operatorname{mix} 8,5 \mathrm{ml} / \mathrm{L}$ air + POC 40 $\mathrm{ml} / \mathrm{L}$ air, sedangkan luas daun terkecil pada konsentrasi ABmix 4,5 ml/L air + POC 100 $\mathrm{ml} / \mathrm{L}$ air.

Tabel 3. Rekapitulasi Hasil Uji BNT 5\% Pengaruh Penggunaan POC Bonggol Pisang terhadap Luas Daun Tanaman Caisim

\begin{tabular}{|c|c|c|c|c|}
\hline \multirow{2}{*}{ Perlakuan } & \multicolumn{4}{|c|}{ Rata-rata Luas Daun $\left(\mathrm{cm}^{2}\right)$} \\
\hline & 14 HST & $21 \mathrm{HST}$ & $28 \mathrm{HST}$ & 35 HST \\
\hline $\begin{array}{c}\mathrm{P} 1: \text { ABmix 4,5 ml/L air + POC } \\
100 \mathrm{ml} / \mathrm{L} \text { air }\end{array}$ & $1,76 a$ & $2,14 a$ & $2.42 \mathrm{a}$ & $2,70 \mathrm{a}$ \\
\hline $\begin{array}{c}\mathrm{P} 2: \text { ABmix 6,5 ml/L air + POC } \\
70 \mathrm{ml} / \mathrm{L} \text { air }\end{array}$ & $1,12 \mathrm{a}$ & $2,84 \mathrm{a}$ & $2,04 \mathrm{a}$ & $2,32 \mathrm{a}$ \\
\hline $\begin{array}{c}\text { P3 : ABmix 8,5 ml/L air + POC } \\
40 \mathrm{ml} / \mathrm{L} \text { air }\end{array}$ & $1,72 b$ & $2,18 \mathrm{a}$ & $2,80 \mathrm{~b}$ & $3,14 \mathrm{~b}$ \\
\hline P4 : ABmix $10,5 \mathrm{ml} / \mathrm{L}$ air & $4,12 \mathrm{~b}$ & $5,00 \mathrm{~b}$ & $6,12 \mathrm{~b}$ & $7,46 \mathrm{~b}$ \\
\hline
\end{tabular}

Keterangan: Angka yang didampingi huruf yang sama pada kolom yang sama, berarti tidak berbeda nyata menurut uji BNT 5\%

$$
\text { Jika kandungan hara cukup }
$$
tersedia maka luas daun tanaman akan semakin tinggi, dimana Sebagian besar asimilat dialokasikan untuk pembentukan daun yang mengakibatkan luas daun bertambah. Jumlah nutrisi ABmix yang diberikan, mengakibatkan jumlah unsur $\mathrm{N}$ yang dapat dimanfaatkan oleh tanaman semakin bertambah [10]. Bonggol Pisang mengandung $3087 \mathrm{ppm} \mathrm{NO}, 1120$ ppm $\mathrm{NH}_{4}, 439$ ppm $\mathrm{P}_{2} \mathrm{O}_{5}$ dan 574 ppm $\mathrm{K}_{2} \mathrm{O}$ [8]. Berdasarkan hasil luas daun yang tertera, menunjukkan bahwa setiap konsentrasi penggunaan $A B m i x$ dan POC Bonggol Pisang dapat mempengaruhi pertumbuhan lebar daun tanaman Caisim.
Daun berfungsi sebagai alat pengambilan zat makanan, pengolahan zatzat makanan, penguapan air, pernafasan. Tumbuhan mengambil zat-zat makanan yang bersifat anorganik. Air beserta garamgaram diambil oleh akar tumbuhan, sedangkan gas asam arang $\left(\mathrm{CO}_{2}\right)$ diambil dari udara melalui mulut daun masuk ke dalam daun [11].

\section{Bobot Segar Tanaman}

Berdasarkan analisis sidik ragam menunjukkan bahwa perlakuan konsentrasi ABmix dan POC Bonggol Pisang berbeda sangat nyata terhadap bobot segar tanaman Caisim. Hasil uji beda nyata pengaruh pemberian kombinasi nutrisi 
terhadap bobot segar tanaman dapat dilihat dari Tabel 4.

Tabel 4. Rekapitulasi Hasil Uji BNT 5\% Pengaruh Penggunaan POC Bonggol Pisang terhadap Bobot Segar Tanaman Caisim

\begin{tabular}{lc}
\hline \multicolumn{1}{c}{ Perlakuan } & Rata-rata Bobot Segar Tanaman (gr) \\
\hline P1 : ABmix 4,5 ml/L air + $100 \mathrm{ml} / \mathrm{L}$ air & $11,14 \mathrm{a}$ \\
$\mathrm{P} 2:$ ABmix 6,5 ml/L air + POC $70 \mathrm{ml} / \mathrm{L}$ & $6,06 \mathrm{a}$ \\
air & $22,14 \mathrm{~b}$ \\
$\mathrm{P} 3:$ ABmix $8,5 \mathrm{ml} / \mathrm{L}$ air + POC $40 \mathrm{ml} / \mathrm{L}$ & \\
air & $46,06 \mathrm{~b}$ \\
P4 : ABmix 10,5 ml/L air &
\end{tabular}

Keterangan: Angka yang didampingi huruf yang sama pada kolom yang sama, berarti tidak berbeda nyata menurut uji BNT 5\%

Hasil pengamatan menunjukkan bahwa perlakuan dengan konsentrasi ABmix 10,5 ml/L air menghasilkan bobot segar tanaman tertinggi $(46,06 \mathrm{gr})$. Sedangkan pada perlakuan konsentrasi ABmix 6,5 ml/L air dan POC Bonggol Pisang $70 \mathrm{ml} / \mathrm{L}$ air menunjukkan hasil yang paling rendah $(6,06 \mathrm{gr})$. Hal ini disebabkan bobot tanaman meningkat seiring dengan bertambahnya ukuran tanaman. Selain itu ketersediaan unsur hara sangat mempengaruhi pertumbuhan dan perkembangan tanaman terutama unsur $\mathrm{N}$. unsur $\mathrm{N}$ yang rendah pada dosis $\mathrm{ABmix} 6,5$ $\mathrm{ml} / \mathrm{L}$ air dan POC Bonggol Pisang $70 \mathrm{ml} / \mathrm{L}$ air mengakibatkan terhambatnya pertumbuhan dan perkembangan tanaman. Fungsi esensial dari unsur $\mathrm{N}$ di dalam jaringan tanaman adalah pembelahan dan pembesaran sel-sel. Rendahnya penyerapan unsur hara mempengaruhi laju fotosintesis dan juga kandungan protein sehingga perkembangan tanaman menjadi tehambat yang mengakibatkan rendahnya hasil bobot segar tanaman [10].

\section{SIMPULAN}

Terdapat pengaruh perlakuan berbagai konsentrasi nutrisi $A B m i x$ dan POC Bonggol Pisang terhadap pertumbuhan tanaman Caisim (Brassica juncea L.) dengan sistem wick. Konsentrasi nutrisi yang paling baik adalah konsentrasi ABmix $8,5 \mathrm{ml} / \mathrm{L}$ air + POC $40 \mathrm{ml} / \mathrm{L}$ air dengan hasil tinggi tanaman umur 35 HST $(21,3 \mathrm{~cm})$, jumlah daun (9 helai), luas daun $(3,14 \mathrm{~cm})$, bobot segar tanaman $(22,14 \mathrm{gr})$.

\section{DAFTAR PUSTAKA}

Irmawati. 2018. Respon Pertumbuhan dan Produksi Tanaman Caisim (Brassica juncea L.) dengan Perlakuan Jarak Tanam. Journal of Agritech Science. 2(1): 30-36.

Dwi, W., Erna, P. dan Endang, S. 2012. Kadar Serat dan Kadar Air serta 
Penampakan Fisik Produk Pascapanen Daun Caisim (Brassica juncea L.) yang Ditanam pada Media dengan Penambahan Pupuk Organik Hayati Cair dan Pupuk Anorganik. Jurnal Bioma. 14 (1): 25-32.

Hartono, E. dan Muhammad, I. 2015. Pengaruh Frekuensi Pemberian Air Irigasi Terhadap Produktivitas Caisim Hidroponik dengan Media Sekam Bakar di P.T. Momenta Agrikultura Lembang. Jurnal Polinela. 7 (1): 1-7.

Badan Pusat Statistik. 2018. Statistik Tanaman Sayuran dan Buah-buahan Semusim Indonesia.

Katalog/Catalog: 5205009.

Kurnia, M. E. 2018. Sistem Hidroponik Wick Organik Menggunakan Limbah Ampas Tahu Terhadap Respon Pertumbuhan Tanaman Pak Choy (Brassica chinensis L.). [Skripsi]. Fakultas Tarbia dan Keguruan. Universitas Islam Negeri Raden Intan. Lampung.

Chaniago, N., Purba. D. W., dan Utama, A. 2017. Respon Pemberian Pupuk Organik Cair (POC) Bonggol Pisang dan Sistem Jarak Tanam Terhadap Pertumbuhan dan Produksi Kacang Hijau (Vigna radiata L. Willczek). Jurnal BERNAS. 13 (1): 1-8.

Kusumaningwati Roro. 2015. Penggunaan MOL Bonggol Pisang (Musa paradisiaca) Sebagai Dekomposer Untuk Pengomposan Tandan Kosong Kelapa Sawit. Journal of ZIRAA'AH, 40 (1): 40-45

Bahtiar, S. A., A. Muayyad., L. Ulfaningtias., J. Anggara., C. Priscilla., dan Miswar. 2016. Pemanfaatan Kompos Bonggol Pisang (Musa Acuminata) untuk Meningkatkan Pertumbuhan dan Kandungan Gula Tanaman Jagung Manis (Zea mays L. Saccharata). Agritrop Jurnal Ilmu-IImu Pertanian. 14 (1): 18-22.

Lalla, M. 2018. Potensi Air Cucian Beras Sebagai Pupuk Organik Pada Tanaman Seledri (Apium graveolens L.). Jurnal Agropolitan. 5 (1): 38-43.

Raihan. 2017. Pertumbuhan dan Perkembangan Tanaman Pakchoy (Brassica chinensis L.) Pada Berbagai Konsentrasi Pupuk ABmix dan Pupuk Organik Cair (POC) dengan Teknik Hidroponik. [Skripsi]. Fakultas Pertanian. Universitas Hasanuddin. Makasar

Tjitrosoepomo Gembong. 2016. Morfologi Tumbuhan. Gadjah Mada University Press. Yogyakarta 